\title{
27. A Hen Enzyme ADP-ribosylates Normal Human and Mutated c-Ha-ras Oncogene Products Synthesized in Escherichia coli
}

\author{
By Hisae Kawamitsu,*) Masanao Miwa,*) Yoshinori Tanigawa,**) \\ Makoto Shimoyama,**) Shigeru Noguchi, $\left.{ }^{*}\right)$ Susumu Nishimura,*) \\ Eiko OHtsuka, ${ }^{* * *)}$ and Takashi Sugimura, ${ }^{*}$ M. J. A.
}

(Communicated March 12, 1986)

Introduction. Ras oncogene products are similar in biochemical properties to guanine nucleotide-binding ( $G$ regulatory) proteins of the transmembrane signaling system such as adenylate cyclase or cGMP phosphodiesterase, ${ }^{1)}$ and have some amino acid sequences homology.2),3) ADP-ribosylation of G regulatory proteins, $\mathrm{Ns}$ and $\mathrm{Ni}$, by bacterial toxins and by cellular ADP-ribosyltransferase stimulates the adenylate cyclase system. ${ }^{4), 5)}$

Ras proteins were produced in Escherichia coli with plasmids bearing chemically synthesized ras genes. ADP-ribosylation of the ras proteins by a cellular enzyme in vitro was studied. We observed that normal human c-Ha-ras oncogene product as well as mutated c-Ha-ras oncogene products undergo ADP-ribosylation in the presence of hen liver enzyme.

Materials and methods. [Adenylate-32P]NAD was purchased from New England Nuclear. ADP-ribosyltransferase was purified from hen liver nuclei and the biochemical characteristics have been previously reported. $\left.{ }^{6}\right)$ Mutated c-Haras protein with a valine at position 12 was produced in Escherichia coli and purified in a homogeneous state. ${ }^{7}$ Similarly, normal c-Ha-ras protein and other mutated proteins were produced and purified (unpublished data).

The reaction mixture contained in $25 \mu \mathrm{l}, 1.2 \mu \mathrm{g}$ of purified c-Ha-ras oncogene product, $10 \mu \mathrm{M}$ [adenylate- ${ }^{32} \mathrm{P}$ ] NAD $(2.5 \mu \mathrm{Ci}), 18 \mathrm{ng}$ protein of hen liver ADPribosyltransferase, $50 \mathrm{mM}$ Tris- $\mathrm{HCl}(\mathrm{pH} 8.0)$ and $10 \mathrm{mM}$ dithiothreitol. The reaction was for $30 \mathrm{~min}$. at $25^{\circ} \mathrm{C}$ and was terminated by the addition of an equal volume of 2-fold concentrated sample buffer used for electrophoresis. ${ }^{8}$ The incubation mixture was electrophoresed directly on $12.5 \%$ polyacrylamide gel containing $0.1 \%$ SDS and $0.38 \mathrm{M}$ Tris- $\mathrm{HCl}$ ( $\mathrm{pH} 8.8) .8$ ) The gel was stained with $0.1 \%$ Coomassie brilliant blue R-250, dried and exposed to Kodak XRP film.

Results and discussion. Both normal human c-Ha-ras oncogene product, p21, and a mutated product with a valine at position 12 instead of a glycine were ADP-ribosylated by hen liver ADP-ribosyltransferase (Fig. 1B, lanes 3 and 4). ADP-ribosylation of the c-Ha-ras proteins was inhibited by the presence of $40 \mathrm{mM}$ arginine methylester or $40 \mathrm{mM}$ nicotinamide (data not shown). When the hen enzyme was heated for $5 \mathrm{~min}$. at $100^{\circ} \mathrm{C}$, the ADP-ribosylation of normal human and mutated c-Ha-ras products was not observed at all (data not shown).

*) Virology Division and Biology Division, National Cancer Center Research Institute, Tsukiji, Chuo-ku, Tokyo 104.

**) Department of Biochemistry, Shimane Medical University, Enya, Izumo 693.

***) Department of Pharmaceutical Sciences, Hokkaido University, Kita-ku, Sapporo 060. 


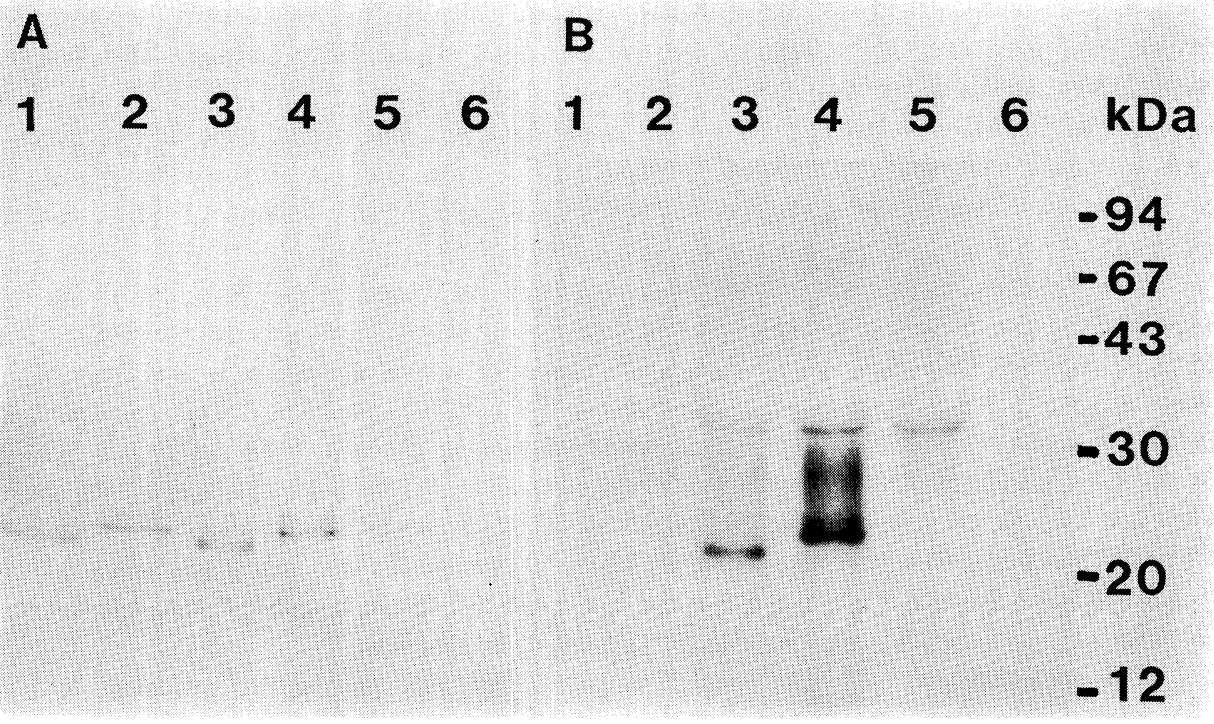

Fig. 1. ADP-ribosylation of normal human and mutated c-Ha-ras oncogene products by hen liver ADP-ribosyltransferase. Purified p21 was incubated with $10 \mu \mathrm{M}\left[{ }^{32} \mathrm{P}\right] \mathrm{NAD}$ in the presence or absence of the hen liver enzyme and then electrophoresed on $12.5 \%$ polyacrylamide gel containing $0.1 \%$ SDS. (A) Stained with Coomassie brilliant blue. (B) Autoradiogram. Lanes: 1, normal c-Ha-ras p21 without hen enzyme; 2, mutated p21 (Val-12) without hen enzyme; 3, normal p21, plus hen enzyme; 4, mutated p21 (Val-12), plus hen enzyme; 5, hen enzyme without ras protein; 6 , no ras protein or hen enzyme, $\left[{ }^{32} \mathrm{P}\right] \mathrm{NAD}$ alone. The standard protein markers are phosphorylase $\mathrm{b} \cdot(94 \mathrm{kDa})$, bovine serum albumin $(67 \mathrm{kDa})$, ovalbumin $(43 \mathrm{kDa})$, carbonic anhydrase $(30 \mathrm{kDa})$, trypsin inhibitor $(20 \mathrm{kDa})$ and cytochrome c $(12 \mathrm{kDa})$.

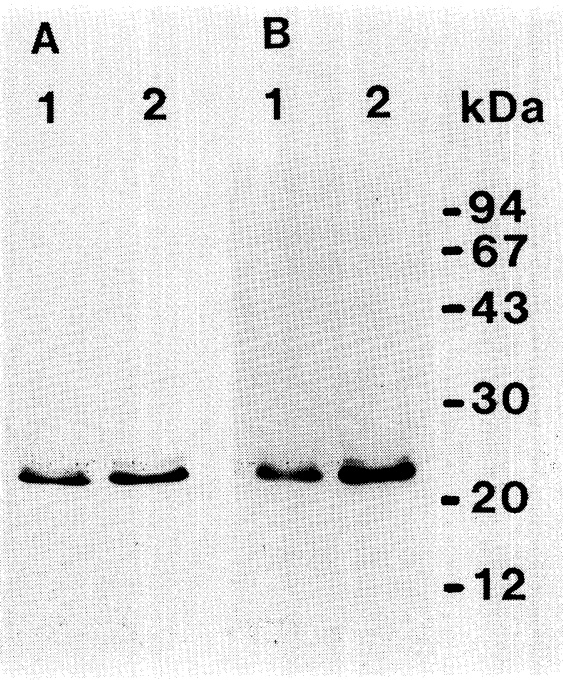

Fig. 2. ADP-ribosylation of two kinds of mutated c-Ha-ras oncogene products by hen liver ADP-ribosyltransferase. (A) Stained gel. (B) Autoradiogram. Lanes: 1, mutated p21 (Leu-61) ; 2, mutated and truncated ras protein (Val-12 and deleted for 18 amino acid residues of carboxylterminus). The standard protein markers are the same as those in Fig. 1. 
The minor band of about 33 kdalton, which was ADP-ribosylated, would be a protein in the enzyme preparation which was copurified through the enzyme purification procedure.

Other mutated c-Ha-ras oncogene products, p21 with a leucine at position 61 and carboxyl-terminal truncated derivative (deleted for 18 amino acid residues) of p21 with a valine at position 12, were also ADP-ribosylated by this enzyme (Fig. 2).

The hen liver enzyme which was used in the present experiment is mainly localized in nuclei but a portion of the enzyme exists in the extranuclear fraction. It is likely that this enzyme causes ADP-ribosylation of proteins in cell membrane such as ras oncogene products. Recently, Tsai et al. reported that a nontransforming v-Ha-ras oncogene product, synthesized in $E$. coli, was ADP-ribosylated by turkey erythrocyte ADP-ribosyltransferase. ${ }^{9)}$ The turkey erythrocyte enzyme and the hen liver enzyme are believed to ADP-ribosylate arginine residues. ${ }^{6}, 10$ ) Normal human c-Ha-ras oncogene product contains 12 arginine residues of the total 189 amino acid residues. ${ }^{11}$ ) One or more of these arginine residues might be ADP-ribosylated by the hen ADP-ribosyltransferase.

The mechanism of cell transformation by ras oncogene product is still unknown. Decreased GTPase activity or alteration of the GTP binding state of ras proteins is suggested to be related to the transforming activity. ${ }^{12), 13)}$ Transducin is a G regulatory protein in the cGMP phosphodiesterase system. ADP-ribosylation of an arginine residue of the $\alpha$ subunit of transducin is associated with a decrease in its GTPase activity. ${ }^{14)}$ It has been reported that ADP-ribosylation of a nontransforming v-Ha-ras protein decreased both GTP binding activity and GTPase activity.9) The effect of ADP-ribosylation of normal and mutated c-Ha-ras proteins on GTP binding and GTPase activities is currently under investigation.

Acknowledgements. This work was supported in part by a Grant-in-Aid from the Ministry of Health and Welfare for a Comprehensive 10-year Strategy for Cancer Control, Japan and a grant for Cancer Research from the Ministry of Education, Science and Culture, Japan.

\section{References}

1) Gilman, A. G.: Cell, 36, 577-579 (1984).

2) Lochrie, M. A. et al.: Science, 228, 96-99 (1985).

3) McCormick, F. et al.: ibid., 230, 78-82 (1985).

4) Ueda, K., and Hayaishi, O.: Ann. Rev. Biochem., 54, 73-100 (1985).

5) Vitti, P. et al.: Proc. Natl. Acad. Sci. U.S.A., 79, 1525-1529 (1982).

6) Tanigawa, Y. et al.: J. Biol. Chem., 259, 2022-2029 (1984).

7) Miura, K. et al.: Jpn. J. Cancer Res. (Gann), 77, 45-51 (1986).

8) Laemmli, U. K.: Nature, 227, 680-685 (1970).

9) Tsai, S.-C. et al.: Proc. Natl. Acad. Sci. U.S.A., 82, 8310-8314 (1985).

10) Moss, J. et al.: ibid., 75, 3621-3624 (1978).

11) Capon, D. J. et al.: Nature, 302, 33-37 (1983).

12) Sigal, I. S. et al.: Proc. Natl. Acad. Sci. U.S.A., 83, 952-956 (1986).

13) Der. C. J. et al.: Cell, 44, 167-176 (1986).

14) Abood, M. E. et al.: J. Biol. Chem., 257, 10540-10543 (1982). 